\title{
GROUND SLOTH EXTINCTION AND HUMAN OCCUPATION AT GRUTA DEL INDIO, ARGENTINA
}

\author{
AUSTIN LONG, PAUL S. MARTIN \\ Department of Geosciences, University of Arizona, Tucson, Arizona 85721-0077 \\ and
}

HUMBERTO A. LAGIGLIA

Museo de Historia Natural, San Rafael (Mendoza) Argentina

\begin{abstract}
A new set of radiocarbon dates from a rockshelter in Mendoza, Argentina addresses the question of the temporal overlap between the presence of an unidentified extinct ground sloth (cf., Mylodontidae) and evidence of human activity. Dung balls on the cave floor, evidently deposited by sloth, are overlain by charcoal, apparently of cultural origin. ${ }^{14} \mathrm{C}$ dates, mostly on charcoal and dung from this shelter, calibrated using recently published curves, as well as the stratigraphy of the deposits from which the samples were collected, suggest that any co-occurrence of humans and ground sloths in this region was brief. In contrast, the single date on mylodon dermal ossicles from this shelter suggests significant time overlap. Replication of this date as well as obtaining new high-precision ${ }^{14} \mathrm{C}$ analyses from this site will be the next priority.
\end{abstract}

\section{INTRODUCTION}

Gruta del Indio is a rockshelter eroded out of a basaltic sequence located at Rincón del Atuel in southern Mendoza province, Argentina ( $\left.34^{\circ} 45^{\prime} \mathrm{S}, 68^{\circ} 22^{\prime} \mathrm{W}\right), 660 \mathrm{~m}$ elevation, $28 \mathrm{~km}$ south of the town of San Rafael. In the stratigraphically lower portions, organic dung balls (boluses or boñigas) $4 \times 6 \mathrm{~cm}$, provided evidence for occupation by large animals, evidently South American ground sloth (cf. Mylodontidae), and the upper strata reveal evidence of human occupation (Lagiglia 1968). Vogel and Lerman (1969) reported the first radiocarbon dates on ground sloth dung, dermal ossicles and charcoal from hearths, which we attribute to human activity at Gruta del Indio, and established the site's antiquity. These dates suggested the possible coexistence of humans and extinct ground sloths near the end of the Pleistocene and the beginning of the Holocene. However, this overlap was not statistically significant, and if it occurred, it must have been brief. D'Antoni (1983) studied the paleoenvironment of both the surrounding area and within the rockshelter. His pollen analyses revealed the beginning of the Holocene to be the onset of higher temperatures and extreme aridity at Gruta del Indio. This climate change corresponded with the change in stratigraphy above the dung-containing zone.

A significant overlap in time between ground sloths and humans would imply their coexistence, whereas no lengthy stratigraphic or temporal overlap would be consistent with Martin's $(1984,1990)$ "blitz" model, in which humans, possibly as predators, were a catastrophic factor in the extinction of large mammals. The present study was initiated to re-examine the stratigraphic evidence for coexistence, and to establish a more extensive base of ${ }^{14} \mathrm{C}$ dates on both the charcoal and the sloth dung from Gruta del Indio.

\section{Gruta del Indio}

Figure 1 is a sketch of the Gruta del Indio shelter. It is one of the few known sites in South America that contain evidence of both extinct megafaunal and human presence. The gruta contains four distinguishable archaeological stages (Lagiglia 1968). The oldest, Atuel IV, contains dung of large mammals, charcoal fragments and apparent firepits. Atuel III, the next younger, contains early formative stage artifacts. The next higher level, Atuel II, contains evidence of agriculture. The most recent stage, Atuel I, is represented by pictographs, one showing Spanish soldiers and two possible boat landings 
(Semper and Lagiglia 1968). The work reported here focuses on the interface between Atuel IV and Atuel III, and specifically, the question of occupational and possible temporal overlap between large mammals and humans.

The presumed identity of the large mammals is based on the size of the dung balls and the morphology of the dermal ossicles recovered from the shelter. Dermal ossicles (pea-sized spherules of bone) are known only in the family Mylodontidae. Teeth associated with the dung represent both mylodontid and megatheriid ground sloths. Artifacts and ${ }^{14} \mathrm{C}$ dates suggest that occupation of the site may have been episodic over a significant range of time (Lagiglia 1968). This study focuses on the stratigraphic interface between the evidence for the earliest human occupation, essentially hearths and charcoal, and that for the latest large faunal visitation, the large dung balls. Seventeen previously unreported ${ }^{14} \mathrm{C}$ dates, in conjunction with newly available calibration curves, have enabled us to place limits on the time overlap of humans and extinct large animals at this locality. Figure 2 shows a vertical face of a trench through the shelter sediments where most of the samples for dating were taken for the present study. We found charcoal overlying dung layers; one firepit intruded into dung. No stratigraphic evidence revealed charcoal mixed with or overlain by dung. (See the Appendix for field collection notes.)

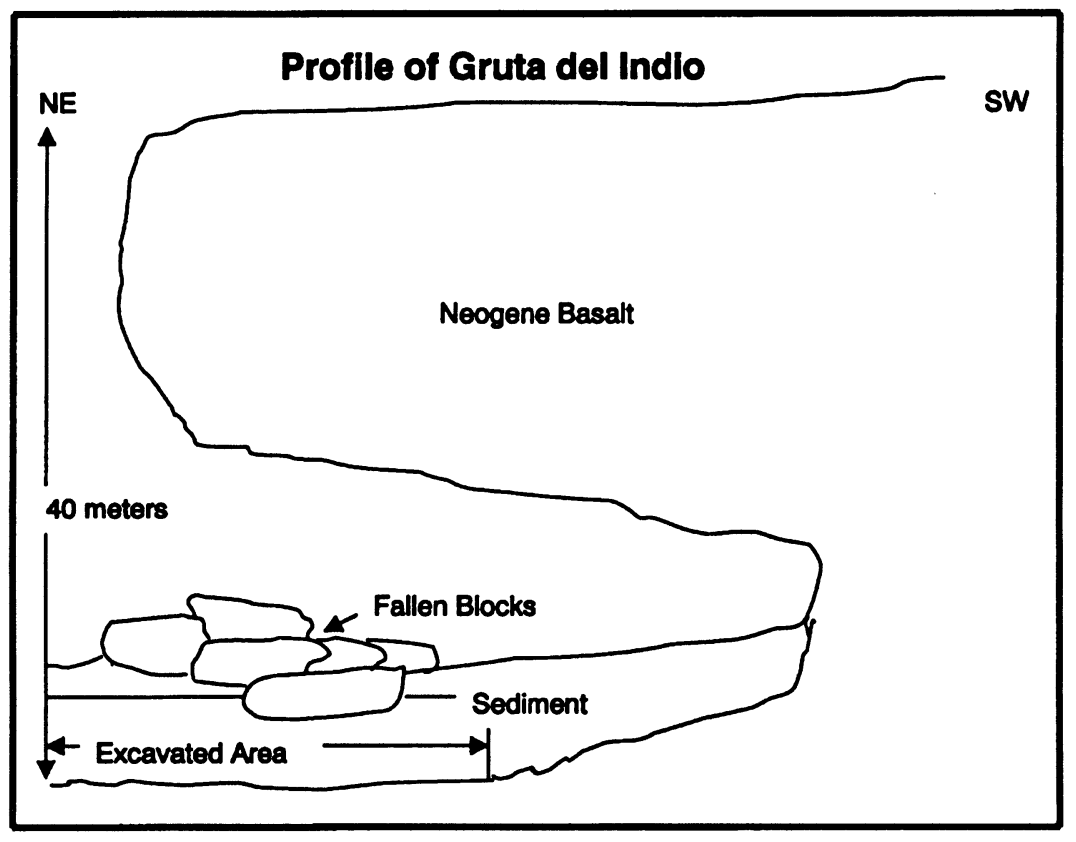

Fig. 1. Schematic section of Gruta del Indio

\section{Radiocarbon Samples and Dates}

Samples of both sloth dung and charcoal were taken in an attempt to obtain the stratigraphically youngest dung and oldest charcoal. Figure 3 is a photograph of one of the well-preserved dung balls. These are smaller than shasta ground sloth boluses from Rampart Cave, Arizona (Long et al. 1973) and much smaller than boluses from Mylodon Cave, Chile. In one case (A-9510) a hearth protruded into the dung layer. Table 1 summarizes the new ${ }^{14} \mathrm{C}$ dates obtained in this study, as well as all previous ${ }^{14} \mathrm{C}$ dates from this shelter, that the authors are aware of, and that are near and older than the Pleistocene/Holocene boundary. See Appendix 1 for sample collection notes. Dates with A-numbers 
between 1000 and 2000 are proportional-counter dates performed in the 1970s; those with A-numbers in the 9000 s are liquid scintillation analyses performed recently in an underground counting chamber. GrN- dates were performed at the Groningen laboratory in the Netherlands in the 1950s and 1960s (Vogel and Lerman 1969) using gas-proportional counters. The last two columns in Table 1 give two calibrated cal yr 2- $\sigma$ ranges representing each ${ }^{14} \mathrm{C}$ date. The next-to-the-last column

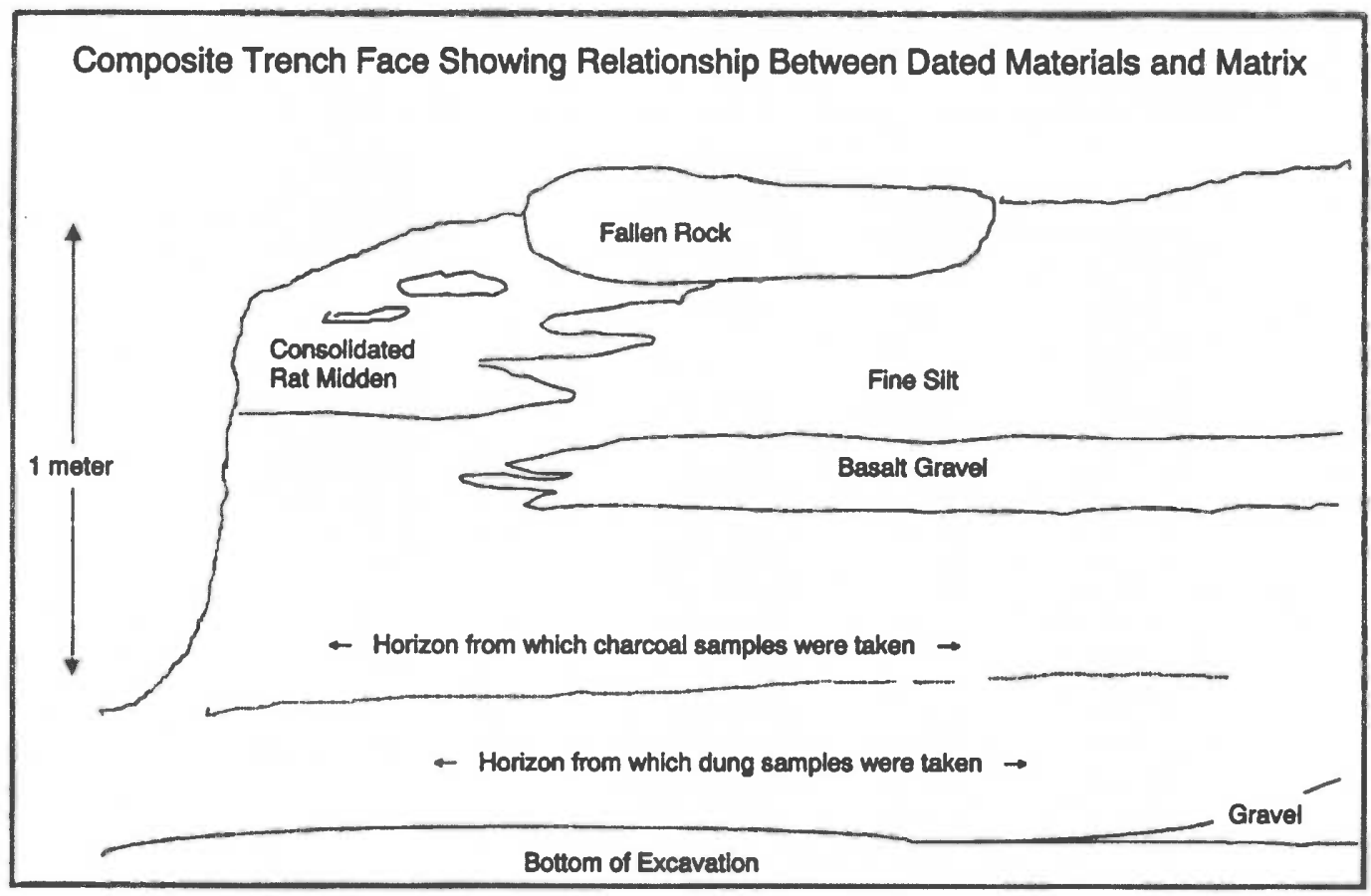

Fig. 2. Composite trench face where most samples were collected

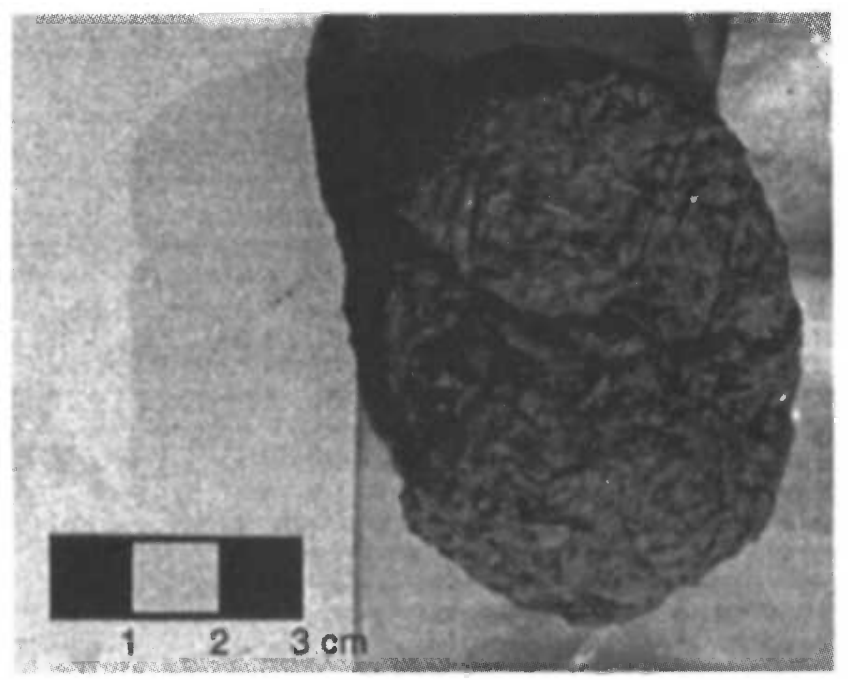

Fig. 3. Photograph of dung ball AL-75-1 
shows the range based on Burr et al. (1998), which includes the ${ }^{14} \mathrm{C}$ calibration data of Bard et al. (1993), and Kromer and Becker (1993), as well the coral-based ${ }^{14} \mathrm{C}$ data of Burr et al. (1998). The calibration range in last column in Table 1 includes the calibration data of Becker and Kromer (1993), and new marine varve ${ }^{14} \mathrm{C}$ data of Hughen et al. (1998). These calibration curves are conservative at the $2-\sigma$ level. The calibration procedure was manual. Table 1 shows calibrated age ranges only for the dates with $1-\sigma$ counting errors $<200 \mathrm{yr}$.

TABLE 1. Radiocarbon Dates on Charcoal, Dung and Mylodon Dermal Ossicles from Gruta del Indio, Argentina

\begin{tabular}{|c|c|c|c|c|c|c|}
\hline $\begin{array}{l}\text { Sample } \\
\text { type }\end{array}$ & Field no. & Lab no. & $\begin{array}{l}\text { Conventional } \\
{ }^{14} \mathrm{C} \text { date }( \pm 1 \sigma)\end{array}$ & $\begin{array}{l}\delta^{13} \mathrm{C} \\
\left(q_{\infty}\right)\end{array}$ & $\begin{array}{l}\text { Calibrated age } \\
20 \text { range (BP)*† }\end{array}$ & $\begin{array}{l}\text { Calibrated age } \\
\text { 20 range } \\
(\mathrm{BP})^{*} \ddagger\end{array}$ \\
\hline Charcoal & AL-75-2 & A-9486 & $10,135 \pm 95$ & -23.2 & $11,020-12,380$ & $10,900-12,400$ \\
\hline Charcoal & AL-75-4 & A-1637 & $9740 \pm 280$ & -22.8 & & \\
\hline Charcoal & AL-75-5 & A-9487 & $10,440+225 /-220$ & -22.4 & & \\
\hline Charcoal & AL-75-7 & A-9489 & $9905 \pm 140$ & -23.0 & $10,580-12,220$ & $10,800-12,360$ \\
\hline Charcoal & AL-75-9 & A-9491 & $9770 \pm 85$ & -22.3 & $10,570-11,670$ & $10,650-11,600$ \\
\hline Charcoal & AL-75-10 & A-9492 & $9825+95 /-90$ & -23.6 & $10,640-11,920$ & $10,800-12,350$ \\
\hline Charcoal & AL-75-13 & A-9495 & $9890 \pm 75$ & -23.4 & $10,920-12,100$ & $10,800-12,350$ \\
\hline Charcoal & AL-75-14 & A-9496 & $9990 \pm 75$ & -23.0 & $11,000-12,150$ & $10,960-12,350$ \\
\hline Charcoal & AL-75-15 & A-9497 & $10,195 \pm 80$ & -23.0 & $11,120-12,440$ & $11,050-12,400$ \\
\hline Charcoal & AL-75-16 & A-9498 & $10,170 \pm 70$ & -23.4 & $11,100-12,400$ & $11,050-12,400$ \\
\hline Charcoal & AL-75-17 & A- 1638 & $10,530 \pm 140$ & -23.1 & $11,680-12,880$ & $11,450-12,980$ \\
\hline Charcoal & $\mathrm{F}-3,2.20 \mathrm{~m}$ & A-1373 & $10,930 \pm 540$ & -- & & \\
\hline Charcoal & Coll. by HAL & GrN-5394 & $8045 \pm 55$ & -17.1 & $8600-9300$ & $9000-9260$ \\
\hline Dung & AL-75-1 & A-9571 & $12,375 \pm 115$ & -24.3 & $14,200-14,600$ & $13,750-14,680$ \\
\hline Dung & AL-75-3 & A-1636 & $10,200 \pm 300$ & -21.8 & & \\
\hline Dung & AL-75-8 & A-9570 & $11,040 \pm 130$ & -22.5 & $12,420-13,700$ & $12,700-13,250$ \\
\hline Dung & AL-75-11 & A-9493 & $10,900 \pm 185$ & -24.7 & $12,000-13,700$ & $12,050-13,250$ \\
\hline Dung & AL-75-12 & A-9494 & $10,285+240 /-230$ & -24.0 & & \\
\hline Dung & Coll. by PSM & A-1282 & $9650 \pm 800$ & - & & \\
\hline Dung & Quad 7 & A-1351 & $10,610 \pm 210$ & -23.4 & & \\
\hline & $(70-80 \mathrm{~cm})$ & & & & & \\
\hline Dung & Quad R-8, 70cm & A-1370 & $24,730 \pm 860$ & -- & & \\
\hline Dung & $\begin{array}{l}\text { Quad } 7 \\
(80-90 \mathrm{~cm})\end{array}$ & A-1371 & $11,820 \pm 180$ & -- & $12,920-14,500$ & $13,050-14,680$ \\
\hline Dung & PSM 6, 0-10 cm & A-1390 & $13,750 \pm 400$ & - & & \\
\hline Dung & $\begin{array}{l}\text { RR-8, } 1.10 \mathrm{~m} \\
\text { Deepest level }\end{array}$ & GrN-5558 & $10,950 \pm 60$ & -22.9 & $12,600-13,800$ & $12,700-13,070$ \\
\hline Wood & $\begin{array}{l}\text { Assoc. with } \\
\text { Dung, Q-RR, } \\
1.0-1.1 \mathrm{~m}\end{array}$ & A-1372 & $-32,000$ & - & & \\
\hline $\begin{array}{l}\text { Mylodon, } \\
\text { Dermal } \\
\text { Ossicles }\end{array}$ & Coll. by HAL & GrN-5772 & $9560 \pm 90 \S$ & -11.5 & $10,200-11,000$ & $10,300-11,600$ \\
\hline
\end{tabular}

*Samples with $\sigma \geq 200$ yr are not included in these columns.

†Calibrated using Burr et al. (1998)

¥Calibrated using Hughen et al. (1998)

\$If this date was not originally adjusted for isotopic fractionation, add $220 \mathrm{yr}$.

\section{Discussion}

We undertook this study to apply stratigraphy and ${ }^{14} \mathrm{C}$ dating to define the time period of overlap, if any, between mammal and human use of this site. In the time since the fieldwork was done, detailed calibrations of the ${ }^{14} \mathrm{C}$ time scale have revealed a period of 500 to $800 \mathrm{yr}$ that predates living dendrochronologically dated trees, during which a relatively high level of ${ }^{14} \mathrm{C}$ in the atmosphere led to 
a "plateau" (horizontal section) of the calibration curve. Unfortunately, this occurred at a time when some of the most interesting and important events in geology, anthropology and paleontology took place. One of these events may be recorded in the Gruta del Indio stratigraphy. Even the highest-precision ${ }^{14} \mathrm{C}$ dates cannot overcome the fact that samples yielding an apparent ${ }^{14} \mathrm{C}$ age of $10,000 \mathrm{BP}$ can have "true" calendar dates anywhere between 11,200 and 11,700 yr.

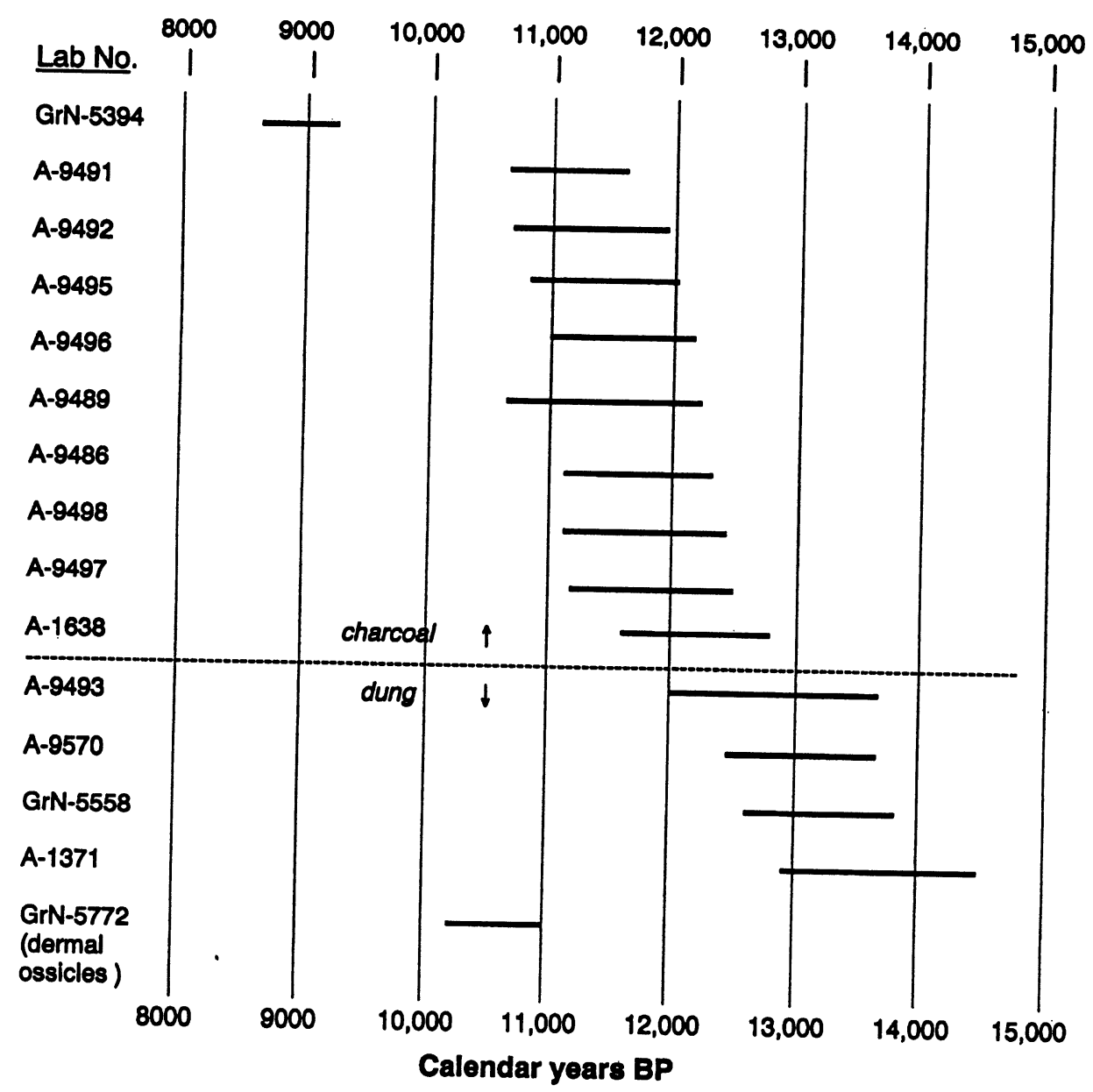

Fig. 4A. Dates with standard deviations $200 \mathrm{yr}$, calibrated using curve of Burr et al. (1998)

The only data selection employed here was to place greater emphasis on ${ }^{14} \mathrm{C}$ dates with lower standard deviations. This essentially amounts to assigning a weighting factor of 1 to those dates with $\sigma<200$, and 0 to those dates with $\sigma>200$. With this restriction, the dates with lower standard deviations show no overlap between the charcoal and the dung at the 1- $\sigma$ confidence level. With the more precise dates, and the 2- $\sigma$ uncertainty range, the calibration procedures employed here yielded the widest, most conservative range of statistically possible calibrated ages for the samples. The general consensus is that the tree-ring-based portion of the calibration curve is secure. More recent tree-ring ${ }^{14} \mathrm{C}$ data of Kromer et al. (1998) show that a further extension of the curve continues its mostly flat trajectory. The coral-based portion of the calibration curve is less certain because the ${ }^{14} \mathrm{C}$ content of corals depends on the ${ }^{14} \mathrm{C}$ of the ocean surface water in which they grew. This is controlled not only 
by the ${ }^{14} \mathrm{C}$ of the atmosphere, but also by the degree of mixing, if any, with deeper water, which may have had lower levels of ${ }^{14} \mathrm{C}$ at times in the past. Marine varves, as employed in the Hughen et al. (1998) calibration curve, also possibly have an unrecognized marine offset. Corrections for this effect are challenging, but it seems likely that the ranges of calibrated dates in Table 1, plotted in Figures 4 A,B conservatively cover the $95 \%$ probability range. It is not possible at this time to know which of the two calibration curves is closer to reality, but for our current data set, it makes little difference. Our data show minor overlap of calibrated age ranges between sloth dung and charcoal ${ }^{14} \mathrm{C}$ dates. We interpret this to mean that coexistence of sloth and humans at Gruta del Indio was brief, if it occurred. It is also possible that if A-1638 and A-9493 were to have higher precision (smaller \pm figures), the charcoal and dung might not overlap at the 2- $\sigma$ level. Unfortunately, sample-size limitations precluded high precision at the time of measurement. Selected samples will be redated by accelerator mass spectrometry (AMS) in an attempt to resolve the question of time overlap.

One ${ }^{14} \mathrm{C}$ date on cf. mylodon ossicles is anomalous. This sample was from a museum collection, not collected or analyzed in this study. Thus, although normal acid-base-acid pretreatment was

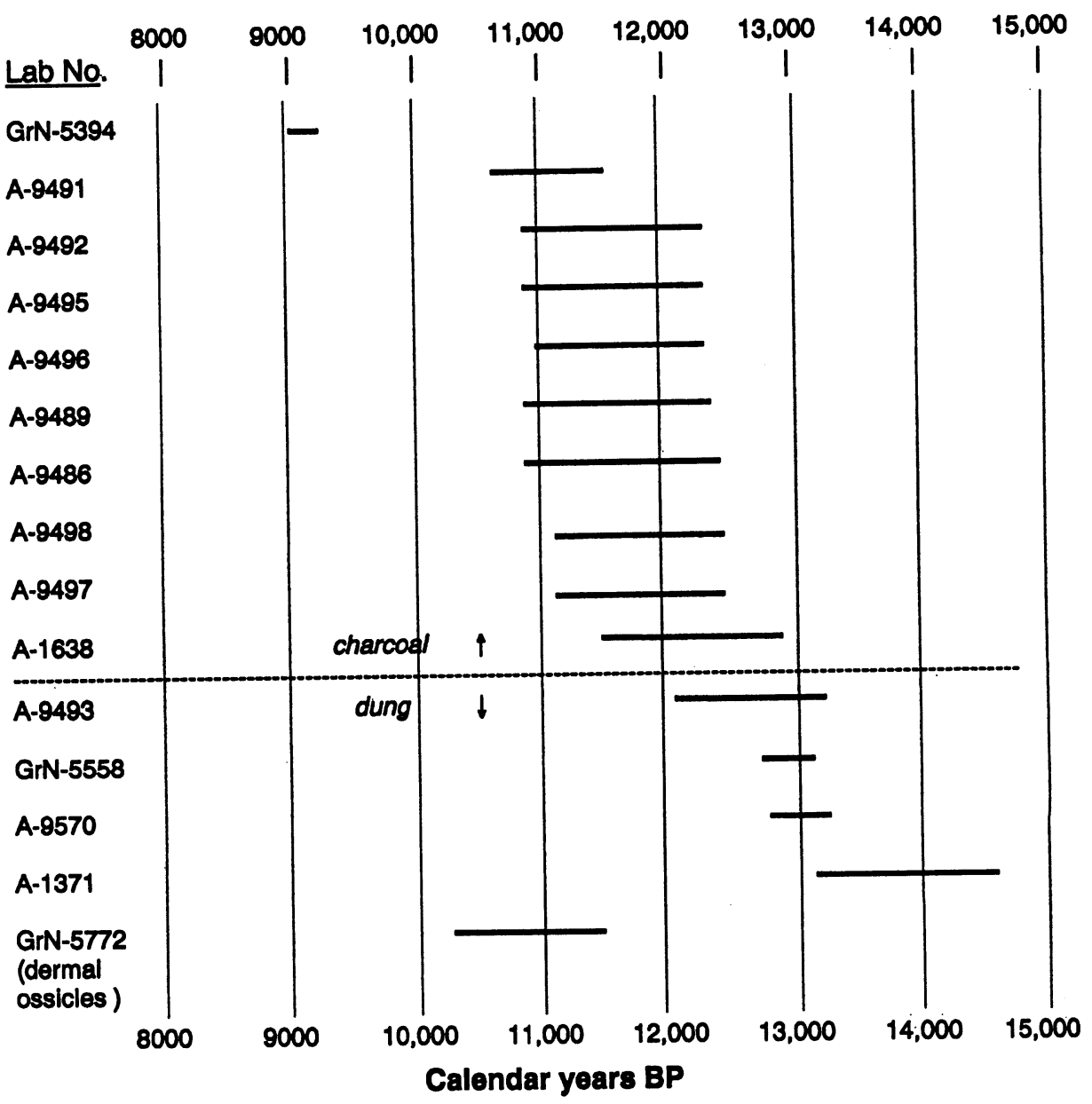

Fig. 4B. Dates with standard deviations $200 \mathrm{yr}$, calibrated using curve of Hughen et al. (1998) 
employed (J. van der Plicht, personal communication 1998), we cannot be certain that preservatives, if applied, were completely removed.

\section{SUMMARY AND CONCLUSION}

Stratigraphic studies and new ${ }^{14} \mathrm{C}$ dates at Gruta del Indio, a rockshelter in west-central Argentina, reveal possible, but not secure evidence for time overlap of extinct faunal remains, probably mylodontid, with human occupation. Stratigraphic overlap was not evident in the exposed trenches. Only for specimens with relatively large \pm figures do calibrated ${ }^{14} \mathrm{C}$ date ranges of dung overlap those of charcoal. A repeat of these dates at higher precision, or new collections and dates, are needed to confirm a time gap between charcoal and dung. New AMS dates should also be carried out on amino acid fractions preserved in dermal ossicles.

If human occupation occurred a few years, or even a few decades after ground sloths occupied the Gruta, and if the ${ }^{14} \mathrm{C}$-dated samples represent the last of the extinct animals and the first evidence of humans, as we attempted to detect in our sampling, more than one pair of the dating uncertainty ranges of charcoal should have clearly overlapped with those of the dung. Except for the dermal ossicles, overlap is ambiguous.

\section{ACKNOWLEDGMENTS}

Several individuals participated in fieldwork, most notably Charles Kepner and Federico Greslebin. We greatly appreciate G. Burr's providing us with the calibration data essential to the interpretation of these dates. The authors graciously acknowledge a grant from the Organization of American States, and from the National Science Foundation, grant SBR-9219868.

\section{REFERENCES}

Bard, E., Arnold, M., Fairbanks, R. G. and Hamelin, B. $1993{ }^{230} \mathrm{Th}-{ }^{234} \mathrm{U}$ and ${ }^{14} \mathrm{C}$ ages obtained by mass spectrometry on corals. In Stuiver, M., Long, A. and Kra, R. S., eds., Calibration 1993. Radiocarbon 35(1): 191-199.

Burr, G. S., Beck, J. W., Taylor, F. W., Recy, J., Edwards, R. L., Cabioch, G., Corrège, T., Donahue, D. J. and O’Malley, J. M. 1998 A high-resolution radiocarbon calibration between 11.7 and $12.4 \mathrm{ka}$ BP derived from ${ }^{230} \mathrm{Th}$ ages of corls from Espiritu Santo Island, Vanuatu. In Stuiver, M., ed., Calibration 1998. Radiocarbon, in press.

D'Antoni, H. 1983 Pollen Analysis of Gruta del Indio. In Rabassa, G., ed., Quaternary of South America and Antarctic Peninsula. Rotterdam, A. A. Balkema: 83105.

Hughen, K. A., Overpeck, J. T., Lehman, S. J., Kashgarian, M., Southon, J., Peterson, L. C., Alley, R. and Sigman, D. M. 1998 Deglacial changes in ocean circulation from an extended radiocarbon calibration. Nature 391: 65-68.

Kromer, B. and Becker, B. 1993 German oak and pine ${ }^{14} \mathrm{C}$ calibration, 7200-9439 BC. In Stuiver, M., Long, A. and Kra, R. S., eds., Calibration 1993. Radiocarbon 35(1): 125-135.

Kromer, B., Spurk, M., Remmele, S., Barbetti, M. and Toniello, V. 1998 Segments of atmospheric ${ }^{14} \mathrm{C}$ change as derived from Late Glacial and Early Holocene floating tree-ring series. Radiocarbon, this issue.

Lagiglia, H. A. 1968 Nuevos aportes a los fechados de radiocarbono de la Argentina. Journal de la Société des Américanistes 57: 161-168.

Long, A. and Martin, P. S. 1973 Death of American ground sloths. Science 186: 638-640.

Martin, P. S. 1984 Prehistoric overkill: The global model. In Martin, P. S. and Klein, R. G., eds., Quaternary Extinctions: A Prehistoric Revolution. Tucson, University of Arizona Press: 354-403.

Martin, P. S. 199040,000 years of extinctions on the 'planet of doom'. Paleogeography, Paleoclimatology, Paleoecology (Global and Planetary Change Section) 82: 187-201.

Semper, J. and Lagiglia, H. 1968 Excavaciones arqueológicas en el Rincón del Atuel (Gruta del Indio), Depto. de San Rafael, (Mendoza, Agr.). Nota preliminar. Revista Cientffica de Investigaciones (Mendoza) 1(4): $87 \mathrm{ff}$.

Stuiver, M. and Reimer, P. J. 1993 Extended ${ }^{14} \mathrm{C}$ data base and revised CALIB $3.0^{14} \mathrm{C}$ age calibration program. In Stuiver, M., Long, A. and Kra, R. S., eds., Calibration 1993. Radiocarbon 35(1): 215-230.

Vogel, J. C. and Lerman, J. C. 1969 Groningen radiocarbon dates VIII. Radiocarbon 11(2): 351-390. 
APPENDIX. Field Collection Notes, Gruta del Indio Archaeological Site, Argentina

\begin{tabular}{|c|c|c|}
\hline Lab no. & Field no. & Description and comments \\
\hline A-1282 & & Dung, Quad 7, level 7, coll. by HAL \\
\hline A-1351 & & Dung, Quad 7, level 7, 70-80 cm, coll. by HAL \\
\hline A-1370 & PSM \#1(A) & Dung, Quad R.8, 70-80 cm, coll. by PSM and HAL \\
\hline A-1371 & PSM \#2(A) & Dung, Quad 7, level 8, 80-90 cm, coll. by HAL \\
\hline A-1372 & PSM \#3(A) & $\begin{array}{l}\text { Wood associated with dung, Quad RR-9, 1.0-1.1m, } \\
\text { coll. by HAL }\end{array}$ \\
\hline A-1373 & PSM \#4 & Charcoal, Quad F-3, 2.20 m, coll. by HAL \\
\hline A-1390 & PSM \#6 & Dung, Quad 7, 0-10 cm, coll. by PSM, HAL \\
\hline A-1636 & AL-75-3 & $\begin{array}{l}\text { Degraded dung ball, } 0-5 \text { red layer, stratigraphically highest } \\
\text { dung in south face of the trench, coll. by AL }\end{array}$ \\
\hline A-1637 & AL-75-4 & $\begin{array}{l}\text { Charcoal from red layer, } 0-5 \text {, stratigraphically lowest charcoal } \\
\text { in south face of the trench, coll. by AL }\end{array}$ \\
\hline A-1638 & AL-75-17 & $\begin{array}{l}\text { Charcoal from F-2 firepit at } 2.68 \mathrm{~m} \text { below original surface, } \\
\text { coll. by AL }\end{array}$ \\
\hline A-9486 & AL-75-2 & Charcoal from west face of $P-6$, near firepit 2, coll. by AL \\
\hline A-9487 & AL-75-5 & $\begin{array}{l}\text { Charcoal from fire hearth no. } 1 \text { in red layer in } 0-5 \text {, south face. } \\
\text { Apparently stratigraphically higher than AL-75-4, though } \\
\text { physically lower, coll. by AL }\end{array}$ \\
\hline A-9489 & AL-75-7 & Charcoal from $\mathrm{E}$ face of $\mathrm{O}-5$, just above dung layer, coll. by $\mathrm{AL}$ \\
\hline A-9491 & AL-75-9 & $\begin{array}{l}\text { Charcoal from } E \text { face of } 0-5 \text { in gray layer, } 1.5-2.0 \mathrm{~cm} \text { above } \\
\text { dung layer, coll. by } \mathrm{AL}\end{array}$ \\
\hline A-9492 & AL-75-10 & $\begin{array}{l}\text { Charcoal from firepit no. 3, evidently dug into sloth-dung } \\
\text { layer, coll. by AL }\end{array}$ \\
\hline A-9493 & AL-75-11 & Dung from top of dung layer near firepit 3 , coll. by $\mathrm{AL}$ \\
\hline A-9494 & AL-75-12 & Single dung ball at top of dung layer, coll. by $\mathrm{AL}$ \\
\hline A-9495 & AL-75-13 & Charcoal from top of hearth layer, coll. by $\mathrm{AL}$ \\
\hline A-9496 & AL-75-14 & $\begin{array}{l}\text { Charcoal from charcoal-rich zone between top and middle } \\
\text { hearth layers, coll. by } \mathrm{AL}\end{array}$ \\
\hline A-9497 & AL-75-15 & Charcoal from middle hearth zone, coll. by AL \\
\hline A-9498 & AL-75-16 & Charcoal from lowest hearth zone, coll. by AL \\
\hline A-9570 & AL-75-8 & Distinct but degraded dung balls from top of dung layer \\
\hline A-9570 & AL-75-1 & $\begin{array}{l}\text { Dung from } P-6,60 \mathrm{~cm} \text { below datum surface, coll. by AL, PSM, } \\
\text { HAL }\end{array}$ \\
\hline GrN-5394 & & $\begin{array}{l}\text { Wood charcoal from hearth above dung horizon, associated } \\
\text { with dermal ossicles of Mylodon listai, Grid RR-9. }\end{array}$ \\
\hline GrN-5558 & & $\begin{array}{l}\text { Dung from deepest level of rockshelter } 1.10 \mathrm{~m} \text { below surface, } \\
\text { RR-8 }\end{array}$ \\
\hline GrN-5772 & & Mylodon dermal ossicles, coll. by HAL \\
\hline
\end{tabular}

